\title{
FREQUENCY OF HEPATITIS B IMMUNITY AND OCCUPATIONAL EXPOSURES TO BODY FLUIDS AMONG BRAZILIAN MEDICAL STUDENTS AT A PUBLIC UNIVERSITY
}

Luiz Carlos Marques de OLIVEIRA(1) \& João Paulo Jordão PONTES(2)

\begin{abstract}
SUMMARY
In the present study the frequencies of immunity against hepatitis B (HB) and of potentially contaminating accidents among medical students of a Brazilian public university were evaluated. Of all the 400 students who should have been immunized, 303 (75.7\%), 66.3\% of whom were women, answered an anonymous, self-administered questionnaire. Serum anti-HBs were determined in 205 of them and titers $\geq 10 \mathrm{UI} / \mathrm{L}$ were considered to be protective. A total of $86.8 \%$ of students had received three doses of $\mathrm{HB}$ vaccine. The frequency of immunity among women $(96.4 \%)$ was higher $(p=0.04)$ than that among men $(87.7 \%)$. Among those who did not have immunity, $12 / 13(92.3 \%)$ had been vaccinated before entering medical school. Only $11 \%$ of the students with complete vaccination had previously verified serological response to the vaccine. A total of $23.6 \%$ reported having been somehow exposed to blood or secretions. Among final-year students, this frequency was $45.0 \%$, being similar among men (47.8\%) and women (43.2\%). Of all these accidents, $57.7 \%$ were due to body fluids coming in contact with mucosa and $42.3 \%$ due to cut and puncture accidents. The results from this study show that: 1) the frequency of immunity against HB is high among the evaluated medical students, although verification of response to vaccination is not a concern for them;2) anti-HBs titers should be verified after complete vaccination and on a regular basis, especially by men; and 3) the frequency of potentially contaminating accidents is high.
\end{abstract}

KEYWORDS: Hepatitis B; Medical Students; Hepatitis B virus; Immunity; Needlestick injuries; Occupational exposures; Needlestick.

\section{INTRODUCTION}

Healthcare workers are a group at risk of acquiring occupational infections after accidental contact with blood or body fluids contaminated with a virus, bacterium, parasite or yeast; the human immunodeficiency virus (HIV) or those of hepatitis B (HBV) or C (HCV) account for most of this risk worldwide ${ }^{22}$. After parenteral exposure with a needle stick or sharp object contaminated by blood infected with HIV, HCV or HBV, the risk of acquiring the infection is $0.3 \%, 1.8 \%$ and about $30 \%$, respectively, among susceptible individuals ${ }^{23}$.

HBV also has been demonstrated to survive in dried blood at room temperature on environmental surfaces for at least one week, and the potential for HBV transmission through contact with environmental surfaces has been demonstrated in investigations of HBV outbreaks among patients and professionals of hemodialysis units ${ }^{23}$. Infection by HBV can be prevented through vaccination, which is considered safe, efficient and cost effective ${ }^{27}$.

Anti-hepatitis B (HB) vaccine was included into the basic vaccination schedule in Brazil in September 1998, with the first dose being given at birth. In the public health network, this vaccine is also freely offered to children and adolescents aged up to 19 years, who have not been vaccinated, and to those belonging to $\mathrm{HB}$ risk groups ${ }^{2}$. Anti-HB immunization is performed with the application of three doses of the vaccine ( 0,1 and 6 months).

Medical students, during their training, are a group of risk to accidental exposure to blood and body fluids due to inexperience and lack of ability in procedures with patients $\mathrm{s}^{6,8,12,13,15,17,21}$. Students enrolled in the medical course of the Faculdade de Medicina da Universidade Federal de Uberlândia, who have not received the vaccine against hepatitis $\mathrm{B}$ (HB), are encouraged to be vaccinated during the pre-clinical course (the first two years of the six-year course) and this vaccine is provided at no cost. The present study aimed to assess the frequencies of vaccination against HBV and hepatitis B immunity among these students. In addition, the frequency of potentially contaminating accidents was also assessed during their academic qualification.

\section{METHODS}

This study was performed among medical students of the Faculdade de Medicina da Universidade Federal de Uberlândia (FAMED/UFU), in the state of Minas Gerais, Brazil, in the first semester of 2009. Students

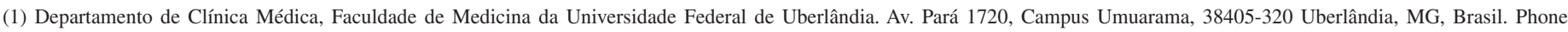
+55.34.3218.2246. E-mail: oliveiralcm@ufu.br

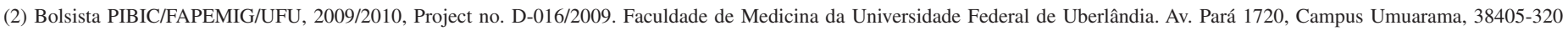
Uberlândia, MG, Brasil. Fone: +55.34.3218.2246. E-mail: pontes_ufu@yahoo.com.br

This paper was presented at the XX "Congresso Brasileiro de Hepatologia", Gramado, RS, September 30 to October 3, 2009.

There are no conflicts of interest.

Financial support: FAEPU (Fundação de Assistência, Estudo e Pesquisa de Uberlândia).

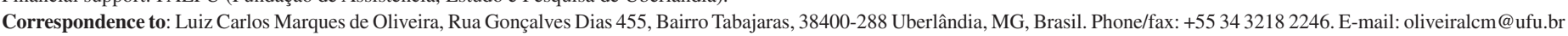




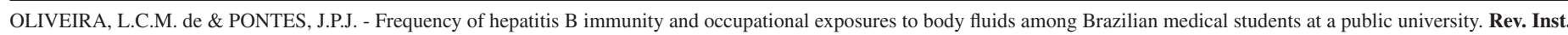
Med. Trop. Sao Paulo, 52(5): 247-51, 2010.

were collectively approached in the classrooms or wherever practical activities were conducted, when the objective of the study was clarified. An anonymous, self-completion questionnaire was subsequently distributed to obtain information about anti-hepatitis $B$ vaccination status, with questions that included time of vaccination, number of doses received and whether he/she had had their serological response to vaccination checked. This questionnaire also included questions about socio-demographic data (sex, age), height, weight, smoking habit, and whether the student had a disease or used medication that could compromise the immune system. This questionnaire was distributed among 400 medical students who should have received three doses of anti-HBV vaccine, i.e. those enrolled in the $2^{\text {nd }}$ through $6^{\text {th }}$ academic years. Each respondent had received at least one $20 \mu \mathrm{g}$ intramuscular dose of recombinant DNA vaccine (Euvax B®, LG Life Sciences, Korea) against $\mathrm{HBV}$ in the deltoid region. Moreover, they were all offered the opportunity to have free serological tests performed to verify their immunity status.

Although this study was not designed to accurately assess the risks of accidental infection in these students, another questionnaire with questions about frequency of accidents with needles/sharp objects and patients' secretions coming in contact with the mucosa, in addition to the procedures adopted in such cases, was also distributed to all 320 students enrolled in the $3^{\text {rd }}$ through $6^{\text {th }}$ academic years. Between the $3^{\text {rd }}$ and $6^{\text {th }}$ academic years, medical students perform activities in outpatient clinics, hospital and laboratories, where there are risks of occupational exposure.

Determination of antibodies to the hepatitis B surface antigen (antiHBs) was performed using microparticle immunoenzymatic assay (AxSYM AUSAB, Abbott, Wiesbaden, Germany), at least one month after the last dose of vaccine, and serum levels equal to or higher than 10 IU/L were considered protective. In addition, the possibility of previous contact with the HBV was verified by determining total antibodies to the hepatitis B core antigen (anti-HBc) with microparticle immunoenzymatic assay (AxSYM CORE, Abbott, Wiesbaden, Germany). Determinations of serological markers of HBV infection are not routinely performed before anti-HB vaccination among medical students at FAMED/UFU. Parameters such as body mass index (BMI) and smoking were also assessed.

With regard to the statistical analysis, Student's t-test was used to compare means of ages; Chi-square test or Fisher's exact test, to compare frequencies of immunities among students; and Mann-Whitney test, to compare the medians of serum levels of anti-HBs. P values $<0.05$ were considered significant. This research project was approved by the institution's Research Ethics Committee and a written consent was obtained from each student participating in this study.

\section{RESULTS}

Of all students approached, 303 completed the questionnaire about anti-HB vaccination, 201 of whom $(66.3 \%)$ were women, with a mean age (standard deviation) of $23.1 \pm 2.2$ years (between 18 and 27 years), and $102(33.7 \%$ ) were men, with a mean age of $23.4 \pm 2.2$ years (between 18 and 32 years). It was observed that 263 students $(86.8 \%)$ had received all three doses of vaccine against HBV recommended, of which $176(66.9 \%)$ were women and $87(33.1 \%)$ were men. Of these, $156 / 263(59.3 \%)$ had been vaccinated before entering medical school, while the others began to be vaccinated during the second semester of the first pre-clinical year. Among the $40(13.2 \%)$ students who had not received all vaccines, three $(1.0 \%)$ had received only one dose and 37 $(12.2 \%)$ had received two doses, and the reasons for the vaccination scheme to be incomplete were as follows: lack of interest (three [7.5\%]), forgetfulness (14 [35\%]) and ongoing vaccination (23 [57.5\%]). Of all the students who had received all vaccines, only 29 (11\%) had verified their immunity by having antibody titers determined, prior to this study.

Antibody titers were determined in 205/303 (67.6\%) students, of which $186(90.7 \%)$ had serum levels of anti-HBs higher than $10 \mathrm{IU} / \mathrm{L}$. When only students who had received all three doses were considered ( $\mathrm{N}=184$ ), the frequency of immunity was $92.9 \%$ (171 students), being higher $(\mathrm{p}<0.01)$ than that among those who had received one (one of three students [33.3\%]) or two (14 of 18 students [77.8\%]) doses of the vaccine. Among students with complete $\mathrm{HBV}$ vaccination schedule, the frequency of immunity was higher in women than men, and also higher in men who had received the vaccines during the medical course, when compared to those who had received them before the medical course (Table 1). Serum levels of anti-HBs were higher in women than men and also among students who had received the vaccine during their preclinical course, when compared to those who had been vaccinated before entering university (Table 2). Two students had a BMI higher than 24.9 and three were smokers; all these five students had immunity against HB.

Table 1

Frequency of immunity against hepatitis B observed in Brazilian medical students of a public university, who received 1, 2 or 3 doses of the HB vaccine

\begin{tabular}{lccccc}
\hline $\begin{array}{l}\text { Number of doses } \\
\text { Gender/(N) }\end{array}$ & \multicolumn{3}{c}{ Serum anti-HBs antibodies } & \multirow{2}{*}{$p$} \\
\cline { 2 - 4 } & \multicolumn{2}{c}{ Negative } & \multicolumn{2}{c}{ Positive } & \\
\cline { 2 - 4 } & $\mathrm{N}$ & $\%$ & $\mathrm{~N}$ & $\%$ & \\
\hline $\mathbf{1}$ dose & 1 & 100 & 0 & 0 & - \\
Male (1) & 1 & 50.0 & 1 & 50.0 & \\
Female (2) & & & & & \\
\hline $\mathbf{2}$ doses & 2 & 50.0 & 2 & 50.0 & 0.20 \\
Male (4) & 2 & 14.3 & 12 & 85.7 & \\
Female (14) & & & &
\end{tabular}

3 doses

Male

\begin{tabular}{lccccc} 
BSV (40) & 8 & 20.0 & 32 & 80.0 & $0.03^{*}$ \\
DSV (33) & 1 & 3.0 & 32 & 97.0 & \\
Subtotal (73) & 9 & 12.3 & 64 & $87.7 * *$ & \\
Female & & & & & \\
BSV (59) & 4 & 6.8 & 55 & 93.2 & 0.12 \\
DSV (52) & 0 & 0 & 52 & 100 & \\
Subtotal (111) & 4 & 3.6 & 107 & $96.4^{* *}$ & \\
\hline TOTAL (205) & 19 & 9.3 & 186 & 90.7 & \\
\hline
\end{tabular}

$\mathrm{BSV}=$ before medical school vaccination; DSV $=$ during medical school vaccination; $\mathrm{N}=$ number of students; $* \mathrm{DSV}>\mathrm{BSV}$; $* * \mathrm{p}=0.04$ : female $>$ male. Fisher's exact test. 
Among the students who had received one dose of the HB vaccine, one out of two women and only one man did not have immunity, and among those who had received two doses of the vaccine, $2 / 4$ (50\%) men and $12 / 14(85.7 \%)$ women had immunity (Table 1$)$, with a median of serum levels of anti-HBs of $36 \mathrm{IU} / \mathrm{L}$ and $50.4 \mathrm{IU} / \mathrm{L}$, respectively.

Students who had received all vaccines against HBV before entering university were those who most frequently had no immunity $(12 / 13$ [92.3\%]) and, among students who had immunity, the median of serum anti-HBs titers were lower than among those who had been vaccinated during their course of medicine (Table 2). Serum levels of anti-HBs higher than $100 \mathrm{IU} / \mathrm{L}$ were observed in 44/59 (74.6\%) women who had been vaccinated before entering the school of medicine and in $46 / 52(88.5 \%)$ women who had been vaccinated during the pre-clinical course $(p=0.10)$. Among men, anti-HBs levels higher than $100 \mathrm{IU} / \mathrm{L}$ were found in 17/40 $(42.5 \%)$ students who had been vaccinated before entering the school of medicine and in $28 / 33(84.8 \%)$ who had been vaccinated during the pre-clinical course $(\mathrm{p}=0.00)$. Tests to determine total anti-HBc were performed in the serum of 205 students who were submitted to anti-HBs determinations, all of whom were negative.

Table 2

Median values of anti-HBs serum levels after complete vaccination of Brazilian medical students of a public university $(\mathrm{N}=184)$

\begin{tabular}{lll}
\hline \multirow{2}{*}{ Gender } & \multicolumn{2}{c}{ Serum anti-HBs levels (IU/L) } \\
\cline { 2 - 3 } & Median & $P$ \\
\hline
\end{tabular}

Female

$\begin{array}{lccc}\text { BSV }(\mathrm{N}=59) & 406 & 0->1000 & 0.01 * \\ \text { DSV }(\mathrm{N}=52) & 1000 & 0->1000 \\ \text { Total }(\mathrm{N}=111) & 576 * * & 0->1000\end{array}$

Male

$\begin{array}{lccc}\text { BSV }(\mathrm{N}=40) & 82 & 0.8->1000 & 0.00 * \\ \operatorname{DSV}(\mathrm{N}=33) & 314 & 7.5->1000 \\ \text { Total }(\mathrm{N}=73) & 141 * * & 0.8->1000\end{array}$

$\mathrm{BSV}=$ before medical school vaccination; $\mathrm{DSV}=$ during medical school vaccination. * DSV > BSV. ** $p=0.00$ - Female > male. Mann-Whitney test.

\section{Table 3}

Frequency of medical students enrolled in the $3^{\text {rd }}$ through $6^{\text {th }}$ academic years who reported previous exposures to blood or secretions

\begin{tabular}{lcc}
\hline Academic years & \multicolumn{2}{c}{ Frequency of occupational exposures } \\
\cline { 2 - 3 } & $\mathrm{N}$ & $\%$ \\
\hline Third $(\mathrm{N}=61)$ & 3 & 4.9 \\
Fourth $(\mathrm{N}=48)$ & 6 & 12.5 \\
Fifth $(\mathrm{N}=51)$ & 16 & 31.4 \\
Sixth $(\mathrm{N}=60)$ & 27 & 45.0 \\
\hline Total $(\mathrm{N}=220)$ & 52 & 23.6 \\
\hline
\end{tabular}

$\mathrm{N}=$ number of students.
Among students enrolled in the $3^{\text {rd }}$ through $6^{\text {th }}$ academic years, 220 completed the questionnaire about occupational accidents. Of these, 52 (23.6\%) reported having been somehow exposed to blood or secretions (Table 3). Among last-year students, this frequency was $45.0 \%(27 / 60$ students), being similar $(\mathrm{p}=0.94)$ among men $(11 / 23$ [47.8\%]) and women (16/37 [43.2\%]). Of all these accidents, 30 (57.7\%) were due to body fluids coming in contact with mucosa and $22(42.3 \%)$ due to cut and puncture accidents. Among the 52 students with biological accidents, 23 (44.2\%) sought medical care and none were submitted to chemoprophylaxis; all patients with whom these students had an accident underwent serological tests, which were negative for HIV, HBV and HCV. Of all 29 students (55.8\%) who did not report an incident, 19 (65.5\%) did not find the occurrence relevant and 10 (34.5\%) felt embarrassed to do this.

\section{DISCUSSION}

In this study, the frequency of immunity against HBV among students with a complete course of vaccination $(92.9 \%)$ is within the expected range of seroconversion in populations of immunocompetent young adults, varying between $90 \%$ and $95 \%{ }^{27}$. The frequency of immunity was higher in female students than males, and poorer response to this vaccine in men has been observed in some studies ${ }^{1,25}$. The median of serum levels of anti-HBs was also higher in females than in males, both among students who had been vaccinated before entering the school of medicine and those who had been vaccinated during the pre-clinical course. Serum levels of anti-HBs, higher in females than males after HB vaccination, were described both in children who had received the first dose of vaccine at birth ${ }^{9}$ and in individuals who had been vaccinated during adulthood ${ }^{16}$.

According to the U.S. Public Health Service, serum levels of anti$\mathrm{HBs}$ equal to or higher than $10 \mathrm{IU} / \mathrm{L}$ are protective against $\mathrm{HBV}^{23}$. With this parameter, about $10 \%$ of the students assessed could be at risk of acquiring hepatitis B. Among the students who had no immunity, the majority $(92.3 \%)$ had been previously vaccinated when enrolling in the school of medicine. It cannot be concluded whether they did not respond to vaccination or whether there was a reduction in serum anti-HBs titers. Anti-HBs titers induced by vaccination declines, often rapidly, in the months or years following a complete course of primary immunization; the decrease is faster in the first 12 months and slower in subsequent years ${ }^{27}$. As these students have no serological evidence of contact with $\mathrm{HBV}$, they should receive a booster dose to verify if there is anamnestic antibody response; in case they do not have this response, they should complete a second three-dose series of vaccine ${ }^{25}$. The chance to respond to a second series of three doses varies between $30 \%$ and $50 \%{ }^{23}$.

To date, none of the international guidelines recommended booster doses for regular bases, and the results of one recent meta-analysis study showed that the protection provided by $\mathrm{HB}$ vaccine remains for at least two decades in the great majority of adequately-vaccinated immunocompetent individuals ${ }^{14}$. However, in certain countries, a serum anti-HBs titer equal to or higher than $100 \mathrm{IU} / \mathrm{L}$ has been adopted as protective immunity, and health professionals with levels between 10 and $99 \mathrm{IU} / \mathrm{L}$ have been instructed to receive a booster dose of the vaccine $\mathrm{T}^{7,18,27}$. In addition, it has been suggested that healthcare workers with anti-HBs concentrations lower than $100 \mathrm{IU} / \mathrm{L}$ should receive a booster dose every two years and their response monitored four weeks after this booster 


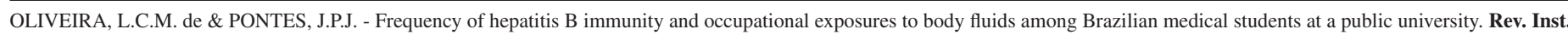
Med. Trop. Sao Paulo, 52(5): 247-51, 2010.

$\operatorname{dose}^{26}$. In the present study, $15.9 \%$ of women and $29.7 \%$ of men $(19.6 \%$ of the total number of students) had levels of anti-HBs between 10 and $99 \mathrm{IU} / \mathrm{L}$, results similar to those found by OATES et al $^{11}$ (1993) among clinical medical students at Birmingham Medical School, in the United Kingdom.

Protective levels of anti-HBs antibody are present in approximately $50 \%$ of young adults after one dose of vaccine against hepatitis B and in $85 \%$ after two doses ${ }^{3}$. In the present study, $85.7 \%$ of female students who received two doses of vaccine had levels of anti-HBs higher than $10 \mathrm{IU} / \mathrm{L}$; the small number of male students who received one or two doses and of female students who received one dose does not enable an analysis to be made. However, even when there is an immunological response to vaccination after two doses, the third dose is required to provide long-term immunity ${ }^{3}$.

Only $11 \%$ of the students had undergone tests to assess the response to vaccination before this study was performed. This is a cause for concern, because several students who participated in this study had antiHBs titers lower than $10 \mathrm{IU} / \mathrm{L}$. Students need to be instructed to check their serum levels of anti-HBs after receiving all recommended three doses of HB vaccine, especially male students and those who had been vaccinated before entering university. Students who do not respond to the initial three doses, the booster dose, and the second series of vaccines, are at risk of acquiring hepatitis B and should be advised about how to prevent an HBV infection and how to perform prophylaxis in case such contact occurs. The frequency of spontaneous searches to find out postvaccination immunity status, as observed in this study, is lower than that found in another study, in the United Kingdom (64\%), where prevalence of hepatitis B is low ${ }^{11}$; this reveals the need to raise students' awareness of the importance of such an assessment.

Among the students who were in the last year of the course of medicine, almost half of them had suffered a potentially contaminating accident during their clinical course, whether with a needle stick or sharp object or through secretions coming in contact with mucosa. Some of the studies addressing the frequencies of needle-stick injuries among medical students in other countries reported rates varying between $14.6 \%$ and $41 \% 5,6,13,21$, while frequencies of injuries due to body fluids coming in contact with mucosa was $8 \%{ }^{17}$ and $20 \%{ }^{12}$. In another study performed in Brazil, the frequency of accidents associated with the training of medical students was $52.3 \%$ among those who were in the last semester of the course, most of which involving needle sticks or sharp objects ${ }^{15}$.

There were no differences in frequencies of accidents between male and female students. These results differ from those of two other studies: one with Australian medical students, in which the frequencies of injuries was $71.4 \%$ in women and $28.6 \%$ in men $^{20}$, and the other from Iran, in which the frequencies of injuries was $73.1 \%$ in men and $26.9 \%$ in women ${ }^{19}$.

Although such accidents are usually stressful events, only $44.2 \%$ of students exposed sought medical care. Alleged reasons for not seeking care were either not considering this as important in the situation or feeling embarrassed to do this. Despite the known risks of acquiring infections inherent in such accidents, not seeking care or not reporting the fact to the proper authorities has been observed in several studies and regions, with frequencies varying between $41 \%$ and $75 \%$ 6,8,13,15,24.
In a study performed in the university hospital of Erlangen, Germany, only $18.8 \%$ of students sought a doctor after the first incident of body fluids coming in contact with mucosa, whereas none sought medical care after the second or third incidents ${ }^{17}$. In another study, where half of the students reported having had needle-stick accidents, it was observed that $76 \%$ of those evaluated did not have any knowledge about post-exposure prophylaxis for hepatitis $\mathrm{B}$ or $\mathrm{C}^{10}$. The alleged reasons usually given by students for not seeking medical care were as follows: accident having been forgotten, underestimation of the risk, being reluctant to admit lack of knowledge about handling certain instruments, avoiding the inconvenience of a report and follow-up, and being afraid of a positive serological test result ${ }^{17}$.

Data from the present study show that the frequency of vaccination against $\mathrm{HBV}$ is high among the evaluated medical students enrolled in the clinical course, although they were not concerned about the verification of serological response to the anti-HB vaccine. Upon admission to the school of medicine, history of vaccination against $\mathrm{HB}$ and serological markers of HBV infection (HBsAg, anti-HBs and anti-HBc) should be determined. Students who have not been vaccinated and who have not had previous contact with HBV should always be aware of the need for vaccination. Determination of serum anti-HBs titers after complete vaccination and on a regular basis should not be neglected, especially not by men.

Moreover, during the clinical course, it was observed that accidents caused by contact with blood or secretions are frequent, which should promote institutional policies on vaccination against hepatitis B and preventive educational practices against such accidents. The universal precautions $s^{4}$ to handle needles or cutting objects and to protect oneself against secretions should be taught and emphasized. Results of the present study show that this should be performed at least at the end of the preclinical stage and beginning of the clinical stage of the course. In addition, it is necessary to maintain a blood and body fluid post-exposure report system, raise students' awareness, encourage them to report occupational accidents, and provide post-exposure care.

\section{RESUMO}

\section{Frequências de imunidade para hepatite $B$ e de exposição ocupacional a fluídos corpóreos entre estudantes de medicina em uma universidade pública brasileira}

Neste estudo avaliaram-se as freqüências de imunidade contra a hepatite B (HB) e de acidentes potencialmente contaminantes em estudantes de medicina de uma universidade pública brasileira. Responderam um questionário anônimo e auto-aplicável 303 de 400 estudantes $(75,7 \%)$ que já deveriam estar imunizados contra a $\mathrm{HB}$, sendo $66,3 \%$ do sexo feminino. Anti-HBs séricos foram determinados em 205 deles e títulos $\geq 10$ UI/L foram considerados como protetores. Tinham esquema vacinal completo $86,8 \%$ dos alunos. A freqüência de imunidade entre as mulheres $(96,4 \%)$ foi maior $(\mathrm{p}=0,04)$ do que entre os homens $(87,7 \%)$. Entre os que não tinham imunidade, 12/13 (92,3\%) tinham sido vacinados antes de ingressarem no curso de medicina. Somente $11 \%$ dos alunos com vacinação completa tinham, previamente, verificado a resposta sorológica à vacina. Do total de alunos, 23,6\% relataram algum acidente potencialmente contaminante, e entre aqueles do último ano esta freqüiência foi de $45,0 \%$, sendo semelhante entre homens $(47,8 \%)$ e mulheres $(43,2 \%)$. De todos estes acidentes, $57,7 \%$ foram com secreções 
e $42.3 \%$ devido a acidentes perfuro-cortantes. Os resultados mostram que: 1) entre os estudantes avaliados é alta a frequiência de imunidade contra a HB, mas a verificação da resposta à vacinação não é uma preocupação entre eles; 2) a verificação dos títulos de anti-HBs deveria ser realizada após o esquema vacinal completo e periodicamente, principalmente entre os homens; e 3) é alta a freqüência de acidentes potencialmente contaminantes.

\section{ACKNOWLEDGEMENTS}

Authors would like to thank all medical students who participated in this study.

\section{REFERENCES}

1. Averhoff F, Mahoney F, Coleman P, Schatz G, Hurwitz E, Margolis H. Immunogenicity of hepatitis B vaccines. Implications for persons at occupational risk of hepatitis B virus infection. Am J Prev Med. 1998;15:1-8.

2. Brasil. Ministério da Saúde. Programa Nacional de Hepatites Virais. Hepatites virais: O Brasil está atento. $3^{\text {a }}$ ed. Brasília; 2008. Available from: http://portal2.saude.gov. br/portal/arquivos/pdf/brasil_atento_3web.pdf. Acessed in 28 June 2010.

3. Centers for Disease Control and Prevention. 1998 guidelines for treatment of sexually transmitted diseases. MMWR Recomm Rep. 1998;47(RR-1):1-118.

4. Centers for Disease Control and Prevention. Update: universal precautions for prevention of transmission of human immunodeficiency virus, hepatitis B virus, and other bloodborne pathogens in health-care settings. MMWR. 1988;37:377-88.

5. Cervini P, Bell C. Needlestick injury and inadequate post-exposure practice in medical students. J Gen Intern Med. 2005;20:419-21.

6. Deisenhammer S, Radon K, Nowak D, Reichert J. Needlestick injuries during medical training. J Hosp Infect. 2006;63:263-7.

7. European Consensus Group on Hepatitis B Immunity. Are booster immunizations needed for lifelong hepatitis B immunity? Lancet. 2000;355:561-5.

8. Gamester CF, Tilzey AJ, Banatvala JE. Medical students' risk of infection with bloodborne viruses at home and abroad: questionnaire survey. BMJ. 1999;318:158-60.

9. Gold Y, Somech R, Mandel D, Peled Y, Reif S. Decreased immune response to hepatitis B eight years after routine vaccination in Israel. Acta Paediatr. 2003;92:1158-62.

10. Khan N, Ahmed SM, Khalid MM, Siddiqui SH, Merchant AA. Effect of gender and age on the knowledge, attitude and practice regarding hepatitis $\mathrm{B}$ and $\mathrm{C}$ and vaccination status of hepatitis B among medical students of Karachi, Pakistan. J Pak Med Assoc. 2010;60:450-5

11. Oates BC, Sidebottom AJ, Maxwell SRJ. Efficacy of hepatitis B vaccination: knowledge among clinical medical students. BMJ. 1993;307:301.

12. Osborn EHS, Papadakis MA, Gerberding JL. Occupational exposures to body fluids among medical students. A seven-year longitudinal study. Ann Intern Med. 1999;130:45-51.
13. Patterson JMM, Novak CB, Mackinnon SE, Ellis RA. Needlestick injuries among medical students. Am J Infect Control. 2003;31:226-30.

14. Poorolajal J, Mahmoodi M, Majdzadeh R, Nasseri-Moghaddam S, Haghdoost A, Fotouhi A. Long-term protection provided by hepatitis B vaccine and need for booster dose: a meta-analysis. Vaccine. 2010;28:623-31.

15. Reis JMB, Lamounier Filho A, Rampinelli CA, Soares ECS, Prado RS, Pedroso ERP Training-related accidents during teacher-student-assistance activities of medical students. Rev Soc Bras Med Trop. 2004;37:405-8.

16. Rendi-Wagner P, Kundi M, Stemberger H, Wiedermann G, Holzmann H, Hofer M, et al. Antibody-response to three recombinant hepatitis B vaccines: comparative evaluation of multicenter travel-clinic based experience. Vaccine. 2001;19:2055-60.

17. Schmid K, Schwager C, Drexler H. Needlestick injuries and other occupational exposures to body fluids amongst employees and medical students of a German university: incidence and follow-up. J Hosp Infect. 2007;65:124-30.

18. Schmid K, Wallaschofski H, Drexler H. Student health policy of a German medical school - results of a cross sectional study concerning students' immunity to vaccinepreventable diseases. Int J Hyg Environ Health. 2004;207:595-600.

19. Shariati B, Shahidzadeh-Mahani A, Oveysi T, Akhlaghi H. Accidental exposure to blood in medical interns of Tehran University of Medical Sciences. J Occup Health. 2007;49:317-21.

20. Smith DR, Leggat PA. Needlestick and sharps injuries among Australian medical students. J UOEH. 2005;27:237-42.

21. Sullivan M, Masters O, Venkatesan P. Needlestick injuries amongst medical students in Birmingham, UK. J Hosp Infect. 2000;44:240-1.

22. Tarantola A, Abiteboul D, Rachline A. Infection risks following accidental exposure to blood or body fluids in health care workers: a review of pathogens transmitted in published cases. Am J Infect Control. 2006;34:367-75.

23. Updated U.S. Public Health Service guidelines for the management of occupational exposures to HBV, HCV, and HIV and recommendations for postexposure prophylaxis. U.S. Public Health Service. MMWR Recomm Rep. 2001;50(RR-11):152 .

24. Waterman J, Jankowski R, Madan I. Under-reporting of needlestick injuries by medical students. J Hosp Infect. 1994;26:149-50.

25. Yen YH, Chen CH, Wang JH, Lee CM, Changchien CS, Lu SN. Study of hepatitis B $(\mathrm{HB})$ vaccine non-responsiveness among health care workers from an endemic area (Taiwan). Liver Int. 2005;25:1162-8.

26. Yoshida T, Saito I. Hepatitis B booster vaccination for healthcare workers. Lancet 2000;355:1464

27. Zuckerman JN. Protective efficacy, immunotherapeutic potential, and safety of hepatitis B vaccines. J Med Virol. 2006;78:169-77.

Received: 6 May 2010

Accepted: 20 July 2010 